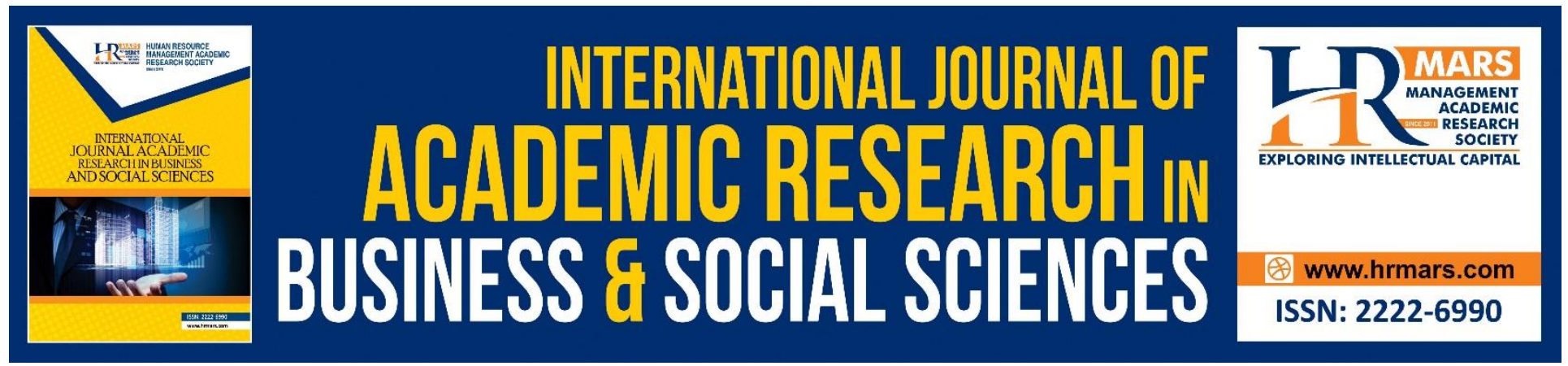

\title{
The Mediating Effects of Relationship Commitment-Trust between Innovation and Fairness on Loyalty in family Takaful: A Literature Review
}

Ahmad Shukri Yazid, Juliana Arifin, Norfadzilah Rashid, Puspa Liza Ghazali, Fauzilah Salleh, Suraya Mahmood, Nadiah Abdul Hamid, Zarinah Abdul Rasit

To Link this Article: http://dx.doi.org/10.6007/IJARBSS/v8-i11/5206 DOI: $10.6007 /$ IJARBSS/v8-i11/5206

Received: 16 Nov 2018, Revised: 29 Nov 2018, Accepted: 11 Dec 2018

Published Online: 13 Dec 2018

In-Text Citation: (Yazid et al., 2018)

To Cite this Article: Yazid, A. S., Arifin, J., Rashid, N., Ghazali, P. L., Salleh, F., Mahmood, S., ... Rasit, Z. A. (2018). The Mediating Effects of Relationship Commitment-Trust between Innovation and Fairness on Loyalty in family Takaful: A Literature Review. International Journal of Academic Research in Business and Social Sciences, 8(11), 1487-1497.

Copyright: (C) 2018 The Author(s)

Published by Human Resource Management Academic Research Society (www.hrmars.com)

This article is published under the Creative Commons Attribution (CC BY 4.0) license. Anyone may reproduce, distribute, translate and create derivative works of this article (for both commercial and non-commercial purposes), subject to full attribution to the original publication and authors. The full terms of this license may be seen

at: $\underline{\text { http://creativecommons.org/licences/by/4.0/legalcode }}$

Vol. 8, No. 11, 2018, Pg. 1487 - 1497

http://hrmars.com/index.php/pages/detail/IJARBSS

JOURNAL HOMEPAGE

Full Terms \& Conditions of access and use can be found at http://hrmars.com/index.php/pages/detail/publication-ethics 


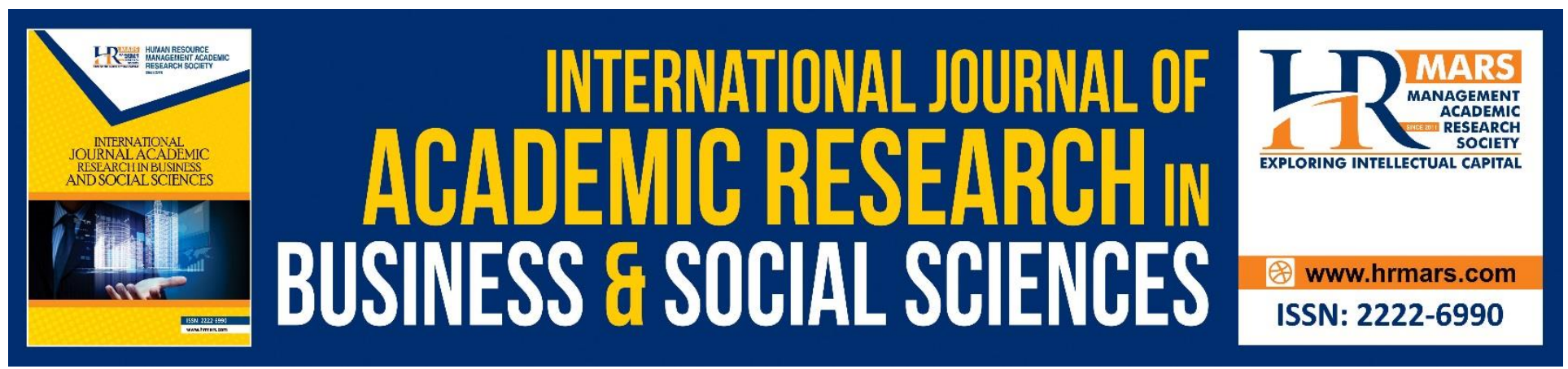

\title{
The Mediating Effects of Relationship Commitment- Trust between Innovation and Fairness on Loyalty in family Takaful: A Literature Review
}

\author{
${ }^{1}$ Ahmad Shukri Yazid, ${ }^{2}$ Juliana Arifin, ${ }^{3}$ Norfadzilah Rashid, ${ }^{4}$ Puspa \\ Liza Ghazali, ${ }^{5}$ Fauzilah Salleh, ${ }^{6}$ Suraya Mahmood, ${ }^{7}$ Nadiah Abdul \\ Hamid, ${ }^{8}$ Zarinah Abdul Rasit \\ ${ }^{1}$ Faculty of Economics and Management Sciences, Universiti Sultan Zainal Abidin, 21300 Kuala \\ Nerus, Terengganu, Malaysia. \\ ${ }^{2}$ Research Institute for Islamic Products \& Civilization (INSPIRE), Universiti Sultan Zainal Abidin, \\ 21300 Kuala Nerus, Terengganu, Malaysia. \\ 7,8 Faculty of Accountancy, Universiti Teknologi MARA, 42300 Bandar Puncak Alam, Malaysia \\ ${ }^{3}$ Universiti Malaya, 50603 Kuala Lumpur, Malaysia \\ Corresponding Author Email: nikmfadzilah@unisza.edu.my
}

\begin{abstract}
Family Takaful is one of the services sectors that continue to play an important role in supporting economic and social development of Malaysia. It is disclosed that the performance of Takaful industry in Malaysia has strongly contributed by family Takaful business rather than general Takaful business. This can be concluded that family Takaful business remained the major income generator for Takaful industry in Malaysia. It is believed albeit macro-level aspects such as the nation's economy, gross domestic products and so forth may lead to this result; other micro-level aspects at the individual level make contributions as well. Therefore, this study requires further examinations of participant loyalty in family Takaful from an innovation and fairness perspective. In additon, it also explores the mediating effects of relationship commitment-trust to explain the factors influencing participant loyalty in family Takaful. This study employs an extensive search for past literatures on the subject. The findings are expected to make a contribution in terms of understanding the factors that could contribute to the loyalty in family Takaful by Malaysian participants.
\end{abstract}

Keywords: Family Takaful, Loyalty, Innovation, Fairness, Relationship Commitment- Trust, and Malaysia. 
INTERNATIONAL JOURNAL OF ACADEMIC RESEARCH IN BUSINESS AND SOCIAL SCIENCES

Vol. 8, No. 11, Nov, 2018, E-ISSN: 2222-6990 @ 2018 HRMARS

\section{INTRODUCTION}

Over the past two decades, the Takaful industry have established itself worldwide, both in Muslim and non-Muslim countries. This industry has experienced a significant development as it is one of the substantial components in the Islamic finance system. The report showed that overall global gross Takaful contribution is estimated to reach US\$14 billion in 2014 from an estimated US\$12.3 billion in 2013 (Rashid, Asfthanorhan, Johari, Hamid, Yazid, Salleh, Abdullah, Ismail, Rasit, et al., 2018). Besides, the gross Takaful contribution in GCC region is accounted around US\$8.9 billion in 2014 from an estimated US\$7.9 billion in 2013. Within the Gulf region, the total gross Takaful contribution for Saudi Arabia was at $77 \%$, followed by UAE, which accounts for $15 \%$. The rest of the Gulf countries account is just $8 \%$ of gross Takaful contribution. In addition to this, the gross Takaful contribution in the ASEAN market is accounted for US\$ 4.2 billion in 2014 from an estimated US\$ 3.5 billion in 2013. Within ASEAN, Malaysia and Indonesia have reported with nearly three-quarters share which is $71 \%$ and $23 \%$ of total gross contribution. Meanwhile, the rest of ASEAN countries accounted for only $6 \%$ of gross Takaful contributions.

In Malaysia, there are two types of Takaful businesses namely family Takaful and general Takaful. Basically the growth of these businesses can be seen through its businesses performance over the last 5 years as shown in the Table 1 below (Aziz et al., 2018). From the table, the total of Takaful business performance in terms of gross contribution increased from RM5, 857 million in 2012 to RM7, 520 million in 2016. It can be seen that for family Takaful business, the gross contribution increased from RM4, 575 million in 2012 to RM5, 742 million in 2016. Similarly for general Takaful business, the gross contribution also increased, albeit only at a slower pace which was from RM1, 282 million in 2012 to RM1, 778 million in 2016. In short, it has to be stressed that the performance of Takaful industry in Malaysia has strongly contributed by family Takaful business rather than general Takaful business which finally remained the major income generator for the Takaful industry in Malaysia.

Through the pattern of gross contribution from the table seems to indicate that family Takaful become a form of savings instrument that is popular especially among Malaysian Muslims in general and has its appeal due to its shari'ah compliant attributes (Alfadhli, Rashid, \& Yaakub, 2018). It is evidenced that Malaysia remains predominantly with family Takaful by making up over $75 \%$ of total global Takaful contributions (Mansor, Akmal, Rashid, Ibrahim, \& Bakar, 2018). The domination of family Takaful business showed how importance it is as a tool for long-term savings and investment, whilst protecting against financial vulnerabilities arising from critical illness, death, disability or unemployment, or providing for children's education. 
INTERNATIONAL JOURNAL OF ACADEMIC RESEARCH IN BUSINESS AND SOCIAL SCIENCES Vol. 8, No. 11, Nov, 2018, E-ISSN: 2222-6990 @ 2018 HRMARS

Table 1.1: Takaful Business Performance in 2012 to 2016

\begin{tabular}{lllllll}
\hline Year & \multicolumn{2}{l}{ Family Takaful } & \multicolumn{2}{l}{ General Takaful } & \multicolumn{2}{l}{ Total } \\
\cline { 2 - 7 } & $\begin{array}{l}\text { RM } \\
\text { million }\end{array}$ & Growth & $\begin{array}{l}\text { RM } \\
\text { million }\end{array}$ & Growth & $\begin{array}{l}\text { RM } \\
\text { million }\end{array}$ & Growth \\
\hline 2012 & 4,575 & $23.5 \%$ & 1,282 & $17.6 \%$ & 5,857 & $41.1 \%$ \\
2013 & 4,807 & $5.1 \%$ & 1,390 & $8.4 \%$ & 6,197 & $13.5 \%$ \\
2014 & 4,787 & $-0.35 \%$ & 1,467 & $5.5 \%$ & 6,254 & $5.15 \%$ \\
2015 & 5,104 & $6.6 \%$ & 1,671 & $13.9 \%$ & 6,775 & $20.5 \%$ \\
2016 & 5,742 & $12.5 \%$ & 1,778 & $6.4 \%$ & 7,520 & $18.9 \%$ \\
\hline
\end{tabular}

Source: Takaful Annual Report and Statistics (2012-2016), Bank Negara

\section{Literature Review}

Nowadays, the family Takaful industry is considered a growing industry with significant progress and continues to play an important socioeconomic role within the economy. Due to this favorable condition for family Takaful development, many of professional belief on retaining the customers by increasing the customer satisfaction and customer loyalty as core marketing strategy (Rashid, Zainol, Salleh, Endut, Yaakub, Ghazali, Afthanorhan, Rashid, \& Daud, 2018). As a result, customer loyalty can be used as a surrogate for market penetration as it creates a stable pool of customers for a firm's product or service (Masud, Daud, Zainol, Rashid, \& Afthanorhan, 2018). Moreover, the customer retention becomes a challenge for all the organizations including family Takaful industry. There are many challenges of keeping customers loyal to a bank in the banking industry (Jamal, Daud, Zainol, Rashid, \& Afthanorhan, 2018). Such challenges consist of stiff competition from other banks, cost of keeping a customer loyal is high, customer needs keep on changing, customer becoming over demanding, lack of clear customer loyalty policies, and lack of knowledge and skills necessary in maintaining customer loyalty.

However, it is importance to retain the existing customers rather than getting a new one as it costs five times more to find the new customers (Rashid, Daud, Zainol, Salleh, Yazid, Endut, Yaakub, Ghazali, Afthanorhan, et al., 2018b). If the loyalty of customers can be raised by 5 \%, a corporation can obtain $25 \%$ to $85 \%$ more profit (Rashid, Daud, Zainol, Salleh, Yazid, Endut, Yaakub, Ghazali, Afthanorhan, et al., 2018a). Thus, identifying the elements that influence customer loyalty represents a thorough process which involves a series of customer's perception that stem from the product and service evaluations. It is clearly stated that keeping the customers is crucial for life insurer as a long -lasting association with the customers result in greater instances of cross-selling and positive recommendation intentions (Musibau et al., 2018). The long term relationship between a customer and a firm makes that firm is worth as it helps improved the firm's image, increase the profit margin of the firm as well as improved the quality of services. For instance, in the case of insurance sector, it is also stated that long term customers can purchase other policies more, take less of a company's time, less sensitive to price, and bring in new customers (Ali, Abdullah, \& Rashid, 2018). 
It is noted the number of empirical studies focused on customer loyalty in the insurance industry is limited (Masud, Daud, Zainol, Rashid, \& Asyraf, 2018a). This is similar when it comes to the context of studies in Islamic insurance or knows as Takaful, particularly in family Takaful. Even though substantial studies have been conducted on Takaful as well as in family Takaful but there is still limited studies focused on loyalty (Mahmod et al., 2018).

This can be concluded that very little is known how the participants's loyalty toward family Takaful could be maintained. Insight into these matters, the Takaful operators should give emphasis to retain the participants in family Takaful and make them loyal to the Takaful operator for survive and prosperity. Hence, the family Takaful industry need to come up with unique strategies to attract and retain their participants or policyholder so that they are not tempted to move to other conventional insurance company.

Therefore, in order to fill the research gap, the researcher has proposed multiple variables which were drawn from innovation diffusion theory, equity theory and relationship commitmenttrust theory. By providing these multiple variables, it also provides a clearer representation of the relationships postulated in the present study. Even better it provides a broader explanation about the factors that affects the participants' loyalty in family Takaful.

\section{Theoretical Background}

\section{Innovation Diffusion Theory (IDT)}

Research on the diffusion of innovation has been widely applied in disciplines such as education, sociology, communication, agriculture, marketing, information technology, and so on (Masud, Daud, Zainol, Rashid, \& Asyraf, 2018b). An innovation is "an idea, practice, or object that is perceived as new by an individual or another unit of adoption" (Masud, Daud, Zainol, Rashid, \& Asyraf, 2018b). Meanwhile, diffusion is "the process by which an innovation is communicated through certain channels over time among the members of a social system" (Noor, Norhayate, Rashid, \& Asyraf, 2018). The IDT argues that "potential users make decisions to adopt or reject an innovation based on beliefs that they form about the innovation" (Noor et al., 2018). As these innovations are communicated to individuals, each individual will perceive the innovation differently. This theory suggested there are five characteristics of an innovation namely relative advantage, compatibility, complexity, trialability and observability (S. A. Ismail et al., 2016).

The main theoretical constructs in IDT studies usually focus on customers' perception or behavior prediction which finally derived any decision making, user acceptance and innovation adoption (Shams et al., 2018). Consequently, the IDT offers an ideal framework for applying in current study which seeks to expand this research area in a product and service innovation context in which the innovation constructs can influence the acceptance and the loyalty in family Takaful. Since family Takaful or Islamic life insurance is subject to an Islamic insurance innovation, where it is an innovative way of conventional life insurance for most people, therefore, it was appropriate to consider using these innovation characteristics from IDT. 
INTERNATIONAL JOURNAL OF ACADEMIC RESEARCH IN BUSINESS AND SOCIAL SCIENCES

Vol. 8, No. 11, Nov, 2018, E-ISSN: 2222-6990 @ 2018 HRMARS

\section{Equity Theory}

Another theory used in this study is Equity Theory (Shams et al., 2018). This theory is based on a principle that peoples' actions and motivations are guided by fairness and that discrepancies in this fairness in an organization will spur them to try and redress it. This theory also recognized that motivation can be affected through an individual's perception of fair treatment in social exchanges. Besides, it postulated that individuals who are fairly rewarded experience satisfaction and will be motivated to engage in a certain behaviour (Shams et al., 2018). When compared to other people, individuals want to be compensated fairly for their contributions (the outcomes they experience match their input. A person's beliefs in regards to what is fair and what is unfair can affect their motivation, attitudes, and behaviors.

As a part of process to develop the participant of family Takaful and Takaful operator relations in this study, fairness can be positioned as a source of competitive advantage (Rashid, Fara, Kamal, Hamid, Ghazali, Yusop, Zaid, Rashid, Fara, et al., 2018). In addition to this, fairness is a multifaceted construct rooted in equity theory (Rashid et al., 2018). As a concept fairness is characterised by a number of features and there are posited to be three main dimensions of fairness, namely, distributive fairness, procedural fairness and interactional fairness (Salleh, Noor, et al., 2018).

\section{Relationship Commitment-Trust Theory}

The Relationship Commitment-Trust Theory (Usop et al., 2018) also used in this study to explain that successful relationship marketing requires the concepts of relationship commitment and trust. The kernel of this theory is that relationship commitment and trust are fundamental to successful relationship marketing and not the power. This central premise of this theory is the simultaneous adoption of relationship commitment and trust as inseparable critical factors for the forming and maintaining business relationships between exchange parties. Consequently, relationship commitment and trust are key factors that shape the behavioral patterns of exchanges between entities (Norliana, Fakhrul Anwar, Wan Norhayate, Norfadzilah, \& Asyraf, 2018). .Besides, this theory can be regarded as one of the theoretical cornerstones of relationship marketing. It is widely applied and utilized in the discipline of marketing (Zainol et al., 2018). It has thereafter also been successfully applied within the context of finance and banking as well (Johari, Rashid, \& Yazid, 2018).

The finance and banking literatures contains examples of using trust and commitment as core concepts of the framework for the research model, rather than utilizing the theory as such (Johari, Rashid, et al., 2018). There are a few study that also used key mediating variables of commitment and trust to reach customer loyalty (M. Ismail et al., 2018). It was proved that trust is able to convince Islamic banking customer to use its services and in fact provide a kind of commitment for them (Johari, Rashid, et al., 2018). The same goes with the family Takaful customers. It is clearly noted when customers have trust and commitment toward the products and services, and merits provided by them can influence their motivation to use or stick with this kind of services. As a result, the researcher applies the relationship commitment-trust theory as key factors that influence customer's loyalty in family Takaful. These key factors consisted of relationship commitment and trust is used as key mediating variable in this study. 
INTERNATIONAL JOURNAL OF ACADEMIC RESEARCH IN BUSINESS AND SOCIAL SCIENCES

Vol. 8, No. 11, Nov, 2018, E-ISSN: 2222-6990 @ 2018 HRMARS

\section{Determinants of Participants Loyalty in family Takaful}

From a comprehensive literature review, this study comes out with multiple variables which were drawn from a few theories in order to explain the participants' loyalty in family Takaful. These factors are highlighted and discussed in brief below.

\section{Relative Advantage}

It is defined as the degree to which the innovation is perceived as better than the idea it supersedes [18]. For the purpose of this study, the relative advantage refers to the capacity of the product to better compete when compared with conventional life insurance.

\section{Compatibility}

It is also defined as the degree to which an innovation is perceived as consistent with the existing values, past experiences and needs of potential adopters (Johari, Tarmizi, Mohd, \& Rashid, 2018). For the purpose of this study, compatibility is refers to the extent of the product that is consistent and compatible with consumers' need, beliefs, values, experiences, and habits.

\section{Complexity/Simplicity}

This represent the end-users' perceived level of difficulty in understanding innovations and their ease of use (Salleh, Ibrahim, et al., 2018). There are a significant number of studies found that complexity or ease of use (simplicity) has an important effect on attitude that lead to behavioral intention or adoption $(42,43,41)$. However, many of previous researchers have used the term simplicity so that the attributes would have the same directionality in terms of their relationship with adoption [44, 45, and 46). Therefore, for the purpose of this study, simplicity was defined to the extent to which the features of family Takaful was viewed as easy to understand.

\section{Trialability}

It is defined as the degree to which an innovation could be tried out by people on a limited basis (Salleh, Ibrahim, et al., 2018). Trialability would create a chance for customers to evaluate an innovation benefits (Kolodinsky \& Hogarth, 2001). For the purpose of this study, the trialability refers to the degree to which the family Takaful may be experimented with on a limited basis.

\section{Observability:}

It is defined as the degree to which outcome of an innovation could be visible to others (Ayers, Jiang, \& Laplante, 2009). For the purpose of this study, the observablity refers to the degree to which the results or benefits of having family Takaful is visible to others.

\section{Distributive Fairness}

Distributive fairness refers as the tested partner's perception of the dyad regarding the equal proportion of the relationship outputs (profit, bonus) and the relationship inputs (investment, effort) of both sides. For the purpose of this study, distributive fairness is refers to the feeling of consumers that their invested efforts are fair in comparison with the final outcomes. 
INTERNATIONAL JOURNAL OF ACADEMIC RESEARCH IN BUSINESS AND SOCIAL SCIENCES

Vol. 8, No. 11, Nov, 2018, E-ISSN: 2222-6990 @ 2018 HRMARS

\section{Procedural Fairness}

Procedural fairness is not concerned with the outcome per se but the policies and procedures through which the outcome is reached. For the purpose of this study, procedural fairness in the context of their study is referred is refers to the fairness of policies and procedures involved in the business transaction effort.

\section{Interactional Fairness}

Interactional fairness defined broadly to the fairness of the interpersonal treatment people receive during the enactment of procedures. For the purpose of this study, interactional fairness refers to the extent to which the individuals feel they have been treated fairly regarding their personal interaction with Takaful's staff throughout the transaction process.

\section{Relationship Commitment}

It is defined as an exchange partner believing that an ongoing relationship with another is so important as to warrant maximum efforts at maintaining it; that is, the committed party believes the relationship is worth working on to ensure that it endures indefinitely. For the purpose of this study, relationship commitment is refers to the willingness or intention to continue maintaining the relationship in the future. Most of the studies discover that the relationship commitment is one of the best factors to explain the consumer behavior. This is supported that relationship commitment is the strongest predictor of members' continuance intention which can play a vital role in customer retention.

\section{Trust}

Trust exists when "one party has confidence in an exchange partner's reliability and integrity". For the purpose of this study, trust is refers to the confidence that the policyholder have in any of institution's reliability and integrity. The past studies revealed that trust is the strongest predictor of members' continuance intention, adoption as well as customer retention (Johari, Tarmizi, et al., 2018).

\section{Conclusion}

This paper proposes a set of determining factors that contribute to the participants' loyalty in family Takaful. From a comprehensive review of literature, there are multiple variables come out from a few theories in this study. Further empirical study is therefore needed to examine whether all of these factors contribute significantly to the participant's loyalty in family Takaful. The researcher expects a positive relationship between the proposed factors with the participants' loyalty in family Takaful

\section{References}

Alfadhli, M. I., Rashid, N., \& Yaakub, N. (2018). The Impact of Internal Audit and its Quality on Sales in Economic Institutions : A Case Study ( Al-Ahlia Cement Company - Libya ) The Impact of Internal Audit and its Quality on Sales in Economic Institutions : A Case Study ( Al-Ahlia Cement Company - Lib. International Journal of Academic Research in Business and Social Sciences, 
INTERNATIONAL JOURNAL OF ACADEMIC RESEARCH IN BUSINESS AND SOCIAL SCIENCES

8(8), 50-65. http://doi.org/10.6007/IJARBSS/v8-i8/4434

Ali, A. R., Abdullah, B., \& Rashid, N. (2018). An Error Analysis Approach in Identifying the Patterns of Mistakes in Jawi Spelling An Error Analysis Approach in Identifying the Patterns of Mistakes in Jawi Spelling. International Journal of Academic Research in Business and Social Sciences, 8(11), 1222-1231. http://doi.org/10.6007/IJARBSS/v8-i11/5164

Ayers, B. C., Jiang, J. (Xuefeng), \& Laplante, S. K. (2009). Taxable Income as a Performance Measure: The Effects of Tax Planning and Earnings Quality. Contemporary Accounting Research, 26(1), 15-54. http://doi.org/10.1506/car.26.1.1

Aziz, K. A., Yazid, A. S., Mahmod, M. S., Rashid, N., Salleh, F., \& Ghazali, P. L. (2018). Enterprise Risk Management ( ERM ) Practices among Malaysian SMEs : The Three Steps Process to identify Adopters and Non- Adopters of ERM for SMEs Enterprise Risk Management ( ERM ) Practices among Malaysian SMEs : The Three Steps Process to identify Adop. International Journal of Academic Research in Business and Social Sciences, 8(11), 1232-1245. http://doi.org/10.6007/IJARBSS/v8-i11/5165

Ismail, M., Zainol, F. A., Norhayate, W., Daud, W., Rashid, N., \& Afthanorhan, A. (2018). Application of Entrepreneurial Marketing to the Marketing Mix : Why it Matters to SMEs in Malaysia ? Application of Entrepreneurial Marketing to the Marketing Mix : Why it Matters to SMEs in Malaysia ? International Journal of Academic Research in Business and Social Sciences, 8(12), 850-865. http://doi.org/10.6007/IJARBSS/v8-i12/5079

Ismail, S. A., Ghazali, P. L., Baharazi, N. Z., Amran, N. A., Salleh, F., Omar, L. Bin, ... Rashid, N. (2016). Application of integration model for recovery fund in takaful education plan. Far East Journal of Mathematical Sciences, 100(2), 301-313. http://doi.org/10.17654/MS100020301

Jamal, R., Daud, W. N. W., Zainol, F. A., Rashid, N., \& Afthanorhan, A. (2018). Unlocking " Black Box ": Mediating Role of Knowledge Process Capability on HRM Practices and Innovative Performance Unlocking "Black Box ": Mediating Role of Knowledge Process Capability on HRM Practices and Innovative Performance. International Journal of Academic Research in Business and Social Sciences, 8(11), 1192-1208. http://doi.org/10.6007/IJARBSS/v8-i11/5162

Johari, R. J., Rashid, N., \& Yazid, A. S. (2018). An Empirical Examination of Undergraduate Accounting Students ' Ethical Judgment : Malaysia Evidence An Empirical Examination of Undergraduate Accounting Students' Ethical Judgment : Malaysia Evidence. International Journal of Academic Research in Business and Social Sciences, 8(12), 669-681. http://doi.org/10.6007/IJARBSS/v8-i12/5064

Johari, R. J., Tarmizi, M., Mohd, H., \& Rashid, N. (2018). A Revisited Note on Internal Audit Function and Good Corporate Governance A Revisited Note on Internal Audit Function and Good Corporate Governance. International Journal of Academic Research in Business and Social Sciences, 8(12), 716-728. http://doi.org/10.6007/IJARBSS/v8-i12/5067

Mahmod, M. S., Aziz, K., Yazid, A. S., Rashid, N., Salleh, F., \& Ghazali, P. L. (2018). A Conceptual Framework of ERM Practices among SMEs IN Malaysia A Conceptual Framework of ERM Practices among SMEs IN Malaysia. International Journal of Academic Research in Business and Social Sciences, 8(11), 1209-1221. http://doi.org/10.6007/IJARBSS/v8-i11/5163

Mansor, M., Akmal, F., Rashid, N., Ibrahim, R. M., \& Bakar, N. A. (2018). The Impact of Human Resouce Practises, Leadership Style And Religiousity on Cyber Deviance The Impact Of Human 
INTERNATIONAL JOURNAL OF ACADEMIC RESEARCH IN BUSINESS AND SOCIAL SCIENCES Vol. 8, No. 11, Nov, 2018, E-ISSN: 2222-6990 @ 2018 HRMARS

Resouce Practises, Leadership Style And Religiousity On Cyber Deviance. International Journal of Academic Research in Business and Social Sciences, 8(11), 1283-1293.

http://doi.org/10.6007/IJARBSS/v8-i11/5169

Masud, H., Daud, W. N. W., Zainol, F. A., Rashid, N., \& Afthanorhan, A. (2018). Past and Future of Human Resource Functions : Are We Done ? Past and Future of Human Resource Functions : Are We Done? International Journal of Academic Research in Business and Social Sciences, 8(11), 1149-1171. http://doi.org/10.6007/IJARBSS/v8-i11/5160

Masud, H., Daud, W. N. W., Zainol, F. A., Rashid, N., \& Asyraf, A. (2018a). A critique of normative commitment in management research. International Journal of Academic Research in Business and Social Sciences, 8(11), 1172-1191. http://doi.org/10.6007/IJARBSS/v8-i11/5161

Masud, H., Daud, W. N. W., Zainol, F. A., Rashid, N., \& Asyraf, A. (2018b). Human resource management practices and organizational commitment: research methods, issues and future directions (2001-2016). International Journal of Academic Research in Business and Social Sciences, 8(11), 1134-1148. http://doi.org/10.6007/IJARBSS/v8-i11/5159

Musibau, H. O., Mahmood, S., Ismail, S., Shamsuddin, Z., Rashid, N., \& Mahmood, S. (2018). Does External Debt Cause Economic Growth ? An Experience from ECOWAS Member Countries Does External Debt Cause Economic Growth ? An Experience from ECOWAS Member Countries. International Journal of Academic Research in Business and Social Sciences, 8(11), 1256-1264. http://doi.org/10.6007/IJARBSS/v8-i11/5167

Noor, N., Norhayate, W., Rashid, N., \& Asyraf, A. (2018). Exploring the Predominant Qualities of Head Teachers towards Achieving School Success Exploring the Predominant Qualities of Head Teachers towards Achieving School Success. International Journal of Academic Research in Business and Social Sciences, 8(11), 1324-1330. http://doi.org/10.6007/IJARBSS/v8-i11/5173

Norliana, A. M., Fakhrul Anwar, Z., Wan Norhayate, W. D., Norfadzilah, R., \& Asyraf, A. (2018). Entrepreneurial Intention from the Islamic Perspective : A Holistic Approach Entrepreneurial Intention from the Islamic Perspective : A Holistic Approach. International Journal of Academic Research in Business and Social Sciences, 8(12), 820-833. http://doi.org/10.6007/IJARBSS/v8i12/5077

Rashid, N., Asfthanorhan, A., Johari, R. J., Hamid, N. A., Yazid, A. S., Salleh, F., ... Salleh, F. (2018). Ethics and Financial Reporting Assurance. International Journal of Academic Research in Business and Social Sciences, 8(11), 1346-1355. http://doi.org/10.6007/IJARBSS/v8-i11/5176

Rashid, N., Daud, W. N. W., Zainol, F. A., Salleh, F., Yazid, A. S., Endut, W. A., ... Abdullah, B. (2018a). The Stakeholders Perceptions towards the Corporate Social Responsibility Reporting The Stakeholders Perceptions towards the Corporate Social Responsibility Reporting. International Journal of Academic Research in Business and Social Sciences, 8(11), 1303-1310. http://doi.org/10.6007/IJARBSS/v8-i11/5171

Rashid, N., Daud, W. N. W., Zainol, F. A., Salleh, F., Yazid, A. S., Endut, W. A., ... Ghazali, P. L. (2018b). The Uses of Financial Reporting Standard for Small Medium Enterprise Companies The Uses of Financial Reporting Standard for Small Medium Enterprise Companies. International Journal of Academic Research in Business and Social Sciences, 8(11), 1331-1338.

http://doi.org/10.6007/IJARBSS/v8-i11/5174

Rashid, N., Fara, N., Kamal, S., Hamid, N. A., Ghazali, N., Yusop, R., ... Abd, N. (2018). The Effect of 
INTERNATIONAL JOURNAL OF ACADEMIC RESEARCH IN BUSINESS AND SOCIAL SCIENCES Vol. 8, No. 11, Nov, 2018, E-ISSN: 2222-6990 @ 2018 HRMARS

Government Support Programs and Compliance Costs on Goods and Services Tax Compliance among Malaysian Batik Manufacturers The Effect of Government Support Programs and Compliance Costs on Goods and Services Tax Compliance among Malaysian Bat. International Journal of Academic Research in Business and Social Sciences, 8(12), 682-694. http://doi.org/10.6007/IJARBSS/v8-i12/5065

Rashid, N., Muhmad, S. N., Hassan, M., Haat, C., Muhmad, S. N., Hashim, H. A., \& Afthanorhan, A. (2018). Risk Management Effectiveness Index Score for Pre and Post Malaysian Code on Corporate Governance 2012 Risk Management Effectiveness Index Score for Pre and Post Malaysian Code on Corporate Governance. International Journal of Academic Research in Business and Social Sciences, 8(12), 729-741. http://doi.org/10.6007/IJARBSS/v8-i12/5068

Rashid, N., Zainol, F. A., Salleh, F., Endut, W. A., Yaakub, N., Ghazali, P. L., ... Daud, W. N. W. (2018). Quality of Financial Reporting towards the Improvement Corporate Governance Mechanism Quality of Financial Reporting towards the Improvement Corporate Governance Mechanism. International Journal of Academic Research in Business and Social Sciences, 8(11), 1339-1345. http://doi.org/10.6007/IJARBSS/v8-i11/5175

Salleh, F., Ibrahim, M. D., Yazid, A. S., Afthanorhan, A., Rashid, N., \& Ghazali, P. L. (2018). Micro Small and Medium Enterprise Demand for General Takaful : Proposed Theoretical Framework and Hypotheses Development Micro Small and Medium Enterprise Demand for General Takaful : Proposed Theoretical Framework and Hypotheses Development. International Journal of Academic Research in Business and Social Sciences, 8(12), 599-612.

http://doi.org/10.6007/IJARBSS/v8-i12/5058

Salleh, F., Noor, D., Ag, H., Yazid, A. S., Salleh, F., Noor, D., ... Rashid, N. (2018). Consumer Behaviour and Insurance Claim Fraud in Malaysia Consumer Behaviour and Insurance Claim Fraud in Malaysia. International Journal of Academic Research in Business and Social Sciences, 8(12), 586-598. http://doi.org/10.6007/IJARBSS/v8-i12/5057

Shams, A., Hoque, M. M., Awang, Z. Bin, Muda, H., Salleh, F., \& Rashid, N. (2018). Ramification of crowdfunding on Bangladeshi entrepreneur's self-efficacy. International Journal of Academic Research in Business and Social Sciences, 8(12), 129-138.

http://doi.org/10.5267/j.ac.2018.04.001

Usop, R., Zainol, F. A., Chik, Z., Norhayate, W., Daud, W., Rashid, N., \& Afthanorhan, A. (2018). Competitive Advantage and Performance : Empirical Investigation on Demographic Factors of Malaysian Hotel Entrepreneurs Competitive Advantage and Performance : Empirical Investigation on Demographic Factors of Malaysian Hotel Entrepreneurs. International Journal of Academic Research in Business and Social Sciences, 8(12), 810-819.

http://doi.org/10.6007/IJARBSS/v8-i12/5067

Zainol, F. A., Aik, C. K., Muthmainnah, N., Hadi, H., Norhayate, W., Daud, W., ... Muthmainnah, N. (2018). Food Security and Food Value Chain : Identifying the Influencing Components in Malaysian Seed Industry Food Security and Food Value Chain : Identifying the Influencing Components in Malaysian Seed Industry. International Journal of Academic Research in Business and Social Sciences, 8(12), 834-849. http://doi.org/10.6007/IJARBSS/v8-i12/5078 